\title{
Oil Bearing Seasonal Crops in India: Energy and Phytoremediation Potential
}

\author{
Mamta Tandon, Padma Vasudevan*, S.N. Naik \& Philip A. Davies ${ }^{\text {a }}$ \\ Centre for Rural Development and Technology, Indian Institute of Technology Delhi, \\ New Delhi - 110016, India \\ ${ }^{\mathrm{a}}$ School of Engineering \& Applied Science, Aston University, Aston Triangle, Birmingham, B4 7ET, UK
}

\begin{abstract}
:
Sustained availability of biomass is a pre-requisite for biomass based energy generation. Seasonal crops of oil bearing plants yield oil seeds (with 30-50\% vegetable oil) as well as biomass residues, both being potential fuels. In this paper, the productivity of common oil bearing seasonal crops is reviewed and the overall energy yields are compared. The yields are significantly enhanced by irrigation, fertilizer application, cultivers selection and other parameters. Waste water which contains considerable amounts of nutrients can be used for irrigation to raise biomass productivity. With good agronomic practices, the energy yields from crops like castor (196 X10 ${ }^{3} \mathrm{MJ} / \mathrm{ha}$ ) are seen to be comparable to that from high yielding perennial grasses (reed canary grass, $195 \mathrm{X} 10^{3} \mathrm{MJ} / \mathrm{ha}$ ). Also the vegetable oil production from seasonal crops is comparable with tree borne oil production. But herein trees start seed production only after 4 or 5 years of maturity, while oil crop yields are annual. Many oil bearing plants bioaccumulate metals and retain these essentially in their roots. The toxins do not reach seeds or oil and the plants are tolerant to toxicity. Hence these plants are useful in phytoremediation of contaminated lands.
\end{abstract}

Keywords: Oil bearing crops, Oil and biomass productivity, Phytoremediation

\section{Introduction:}

With depleting oil sources, biomass is seen as a valuable resource not only for renewable energy generation but also as chemical feed stock (Bender, 2000; Demirbas, 2006; Fernando et al., 2006). Different types of biomass being used for energy generation are woody biomass, grasses, agro residues and oil bearing plants (tree based and seasonal) (Mckendry, 2002a; 2002b). Seasonal oil bearing crops can be harvested annually, 
yielding not only valuable oil but also significant amounts of biomass residues. The oil itself can, in principle, be used as liquid fuel directly or after conversion by transesterification to bio-diesel (Hossain et al., 2011, Meher et al., 2006). The total heating value of plant parts and oil can be obtained by complete combustion of these under pure oxygen atmosphere. This is the maximum energy potential of the fuel. However, if biomass is converted through chemical, thermochemical/biochemical pathways (Hornung et al., 2011, Naik et al., 2010, McKendry, P., McKendry, 2002b) to liquid, gaseous or solid fuels the energy potential of the products thus obtained will be different. In this paper we are considering the overall heating value by direct combustion.

Given the limited availability of land and water, raising biomass for energy is often seen to be conflicting with food production. This can be resolved by judicious management of land, soil and water and raising plants appropriate to the given agro-ecological zone. For example, wastelands and contaminated lands can be used for raising energy crops. In addition, waste water from different anthropogenic activities can be used for meeting irrigation and other needs in such crop management. For example, domestic waste water with considerable amount of macro nutrients like nitrogen, phosphorous and potassium (NPK) and a variety of micro nutrients (Vasudevan et. al, 2010) can be used for fertigation (Toky et. al, 2011). This solves the problem of waste water disposal while supplying valuable nutrients and water to plants and thus enhancing biomass production (Pandey et. al, 2011). Clearly there has to be a judicious choice of crops matching the land, soil and climate conditions and also considering the long term effects on soil and environment especially by contaminants.

Industrial and agricultural effluents and mining areas generally carry hazardous and toxic components such as heavy metals, often specific to the system. Many of these contaminants are bioaccumulated with a high concentration factor by the micro and macro flora and fauna. While this poses a health hazard, bioaccumulation of toxicants by plant biomass which do not go into the food chain can be beneficial for remediation of soil and water. Recent studies have indicated that many oil bearing crops exhibit high phytoremediation potential since they accumulate different heavy metals to a significant 
extent (Shi and Cai, 2009). Since these are short rotation crops feasibility of repeatedly removing the toxic metals from soil by their growth is of value.

It is important to know the level of accumulation of metal by various plant parts. Any metal accumulation in part of the plant used as food or fodder will lead to translocation of these metals into food chain. Although metal in non-edible parts of the plant could also pollute the environment, if the level of metal accumulation is below permissible limits for a given application, the plant part can still be recommended for use. Such limits vary with the type of use for example, $\mathrm{Pb}, \mathrm{Cd}$ and $\mathrm{Cr}$ in herbs depending on their applications, the limits are in the order of $1 \mu \mathrm{g} / \mathrm{g}$ (WHO, 2005; FAO, 2006 and Maobe et al., 2012). A good tolerance of plant toward heavy metals coupled with an increased metal accumulation capacity would thus contribute to an efficient removal of heavy metals from a polluted area.

The oil bearing plants may be categorized into those which yield edible and non-edible oil. The popular edible oils are mustard, sunflower, safflower, cottonseed, corn oil, groundnut oil and sesame oil. Examples of non-edible oils are jatropha, rapeseed and castor. Additionally there are plants such as flax and hemp which produce oil but yields are low. In all the cases after removal of the oil bearing seeds, there is considerable amount of biomass residues, which can be used as fuel for direct burning or processed to fuels by pyrolysis.

The focus of this paper is on the productivity of oil bearing plants and use of waste water and wastelands for enhancing their yields. The level of bioaccumulation and partitioning of metals and other contaminants by these plants and the feasibility of using the plants for phytoremediation are considered.

\section{Biomass productivity of oil bearing seasonal crops}

In this section productivity of seasonal oil bearing crops in the context of energy potential is seen in terms of both oil seeds and biomass residue. Productivity of some oil bearing perennial trees and perennial grasses has been included for the purpose of comparison. 


\subsection{Seed and oil yield}

Rajvanshi et al., 2007 extensively reviewed the prospects of biofuels in India from oil bearing crops. They showed that under rainfed conditions the potential yield of oil seeds varies in the range 500-1500 kg/ha, the highest being for groundnut and castor. Under irrigated condition the seed yield increases for all the crops; the increase is 1.1 to 2.3 times depending on the crop (Table 1). The highest increase being registered for castor and mustard. Thus on irrigation the seed yield reaches $3000 \mathrm{~kg} / \mathrm{ha}$ for castor though only $616 \mathrm{~kg} / \mathrm{ha}$ for sesame. The average oil content in the seed varies between 30 to 50\%. Castor, groundnut and sesame are the richest (50\%) in oil. Thus in terms of the seed yield, percentage oil content in the seed and the feasibility of increasing seed yield by irrigation, castor stands out as having the highest potential for oil production besides groundnut.

It would be of interest to compare these data with the oil production potential for selected tree based oils (TBO) compiled by the National Oil Seed and Vegetable Oil Development Board, India (Table 2). There is generally a waiting period of 4 to 5 years before trees start yielding seeds. It is seen that in case of trees, annual seed yield increase as the trees mature. Percentage oil content of the seeds is in the region 30 to $50 \%$. Overall, in terms of oil yield seasonal crops are comparable to tree based oil at lower maturity of trees.

\subsection{Biomass Yield}

In addition to oil, oil seed crops also give considerable amount of biomass residue in the form of stalk, stover etc. as shown in table 1. Crop residue to seed ratio varies in the region 2 to 6. It is high for mustard (6.14 times) and rapeseed (4.88 times), and for castor, sunflower, safflower and sesame it is nearly 3 times.

The average crop residue yields under rainfed condition are in the range 3000-4000 kg/ha except for sesame and linseed. Under irrigated conditions the yield of crop residue also increases by 1.1 to 2.3 times as in the case of oil. Thus the average dry crop residue is quite high - up to $9000 \mathrm{~kg} / \mathrm{ha}$ for castor under irrigated condition. In fact other reports have shown that dry castor stalk, a byproduct of castor plant cultivated for its seeds, has 
an average yield of $10000 \mathrm{~kg} / \mathrm{ha}$, which is higher than average yield of forest in temperate zone (Grigorion and Ntalos, 2001). Further, on extraction of oil from many oil seed significant amounts of husk and meal are obtained as residue. For example, for each ton of castor oil, 1.31 ton of husk and 1.13 ton of meal are produced (Lima et al., 2011). The yield of crop and oil residues is important as they are valuable bioenergy resource.

The productivity of oil and biomass residue of oil bearing plants may be compared with productivity of perennial grasses (Table 3). The four most important perennial rhizomatous grasses (dry matter, DM) for bioenergy production being investigated in the US and Europe are switchgrass (Panicum virgatum) (yield 5000-23000 kg/ha in a year), miscanthus (Miscanthus spp.) (yield 5000-44000 kg/ha in a year), reed canary grass (Phalaris arundinacea) (yield 7000-13000 kg/ha in a year) and giant reed (Arundo donax) (yield 3000-37000 kg/ha in a year) (Lewandowski et al., 2003). It may be noted that the biomass yield from some oil bearing crops like castor is comparable to giant reed and lower end of the range from other grasses.

\subsection{Energy Potential}

It must be noted that in case of perennial grasses there is no oil production and in case of tree-borne oilseeds (TBO) there is no biomass residue. But oil bearing seasonal crops produce both oil and residues which may be used for energy production. Hence it is useful to compare plants in terms of overall energy production. Heating value for dry perennial grasses has been reported to vary between 9.2 to $19.3 \mathrm{MJ} / \mathrm{kg}$ (Lewandowski et al., 2003). Crop stover and stalks also have heating value of this order. For the purpose of calculation an average heat value of $15 \mathrm{MJ} / \mathrm{kg}$ for dry biomass has been taken. On this basis the energy potential of perennial grasses are shown in table 3 (last column). Heating values for some of the tree based seed oils have been reported as Karanja 39.2, Jojoba 43.25 and Jatropha $38.8 \mathrm{MJ} / \mathrm{kg}$ (Hossain et al., 2011). An average heating value for seasonal oil bearing seed oil has been taken for calculations as $41.6 \mathrm{MJ} / \mathrm{kg}$ (Rajvanshi et al., 2007). Using these conversion factors the total energy production from seed oil and residue under rainfed condition is seen to vary from $82.0 \times 10^{3} \mathrm{MJ} / \mathrm{ha}$ for castor to $31.6 \mathrm{X}$ $10^{3} \mathrm{MJ} / \mathrm{ha}$ for sesame in a season (Table 4). Under irrigated conditions due to increase in 
yields it is $196.1 \times 10^{3} \mathrm{MJ} / \mathrm{ha}$ for castor to $37.8 \times 10^{3} \mathrm{MJ} / \mathrm{ha}$ for sesame in a season. It is seen from tables 3 and 4 that the total energy potential of oil seed crops is comparable to that from perennial grasses.

\subsection{Enhancing Oil Crop Productivity}

Irrigation is seen to enhance the productivity by 1.5 to 2.5 times for oil bearing seasonal crops. It is known that use of fertilizer can further increase crop productivity. For example, the agronomic aspects of sesame crop productivity grown on sandy soil were investigated by Abdel-Sabour and El-Seoud (1996). Dry matter accumulation was used as an indicator of the effectiveness of such treatments on plant growth. In addition, the contents of nitrogen-phosphorus-potassium, chlorophyll, total protein, oil and carbohydrates were determined in plant tissue as physiological parameters. All compost treatments stimulated sesame growth and enhanced its pigment, carbohydrate and mineral contents. Compost addition enhanced seed several fold depending on compost type and rate, indicating that organic compost increases not only the vegetative growth of sesame but also its seed production. While the chemical constituents of sesame seeds (oil, carbohydrate and total protein) showed no variation when expressed as relative data (\%), while the absolute results expressed as gram per plant exhibited significant increases.

Another study was conducted by Akbari et al., (2011) on effect of biofertilizer, nitrogen fertilizer and farmyard manure on grain yield and seed quality of sunflower (Helianthus annus L.). The results showed that both grain and biological yield produced were better on applying a combination of nitrogen fertilizer and farmyard manure as compared to using either component alone. Maximum grain and biological yields were $2823 \mathrm{~kg} / \mathrm{ha}$ and $9918 \mathrm{~kg} / \mathrm{ha}$ respectively. The oil content in the seed was $49.4 \%$. This is 1.7 times higher than what is reported in table 1 for irrigated crop yields.

If waste water is used for irrigation, biomass productivity can be further enhanced due to the presence of nutrients in the water. Domestic waste water is rich in nutrients and does not generally contain toxins (Thapliyal et al., 2011). In a study done on salix trees as vegetative filters for domestic waste water, $30-100 \%$ increase in total biomass was 
recorded as compared to rainfed plantation (Borjesson et al., 2006). In another study, using grey water, dry biomass yield increased with respect to control (groundwater) to a significant extent for Encalyptus hybrid (143\%), Pospulus deltoids (54\%), Salix alba (274\%) and Melia azedarach (321\%) (Pandey et al., 2011). Most of the literature reports on waste water irrigation refer to the use of industrial effluents (either raw or synthesized water), which contain metals and other toxicants. The bioaccumulation from these is reviewed below simultaneously evaluating the feasibility of phytoremediation by the plants.

\section{Bioaccumulation of metals and phytoremediation of soil}

Phytoremediation of heavy metal contaminated soil is a technology used to remove metals from soils. It has attracted much attention because it is an environmentally friendly and relatively cheap technique (McGrath, 1998; McGrath et al., 2002). There are two basic strategies under development. The first is the use of hyper accumulator plants that have the capacity to hyper accumulate heavy metals, and the second is chemical chelate-enhanced phytoextraction (Salt et al., 1998). The major problem hindering plant remediation efficiency is that some of the metals are immobile in soil and their availability and phytoextraction rate are limited by solubility and diffusion to the root surface. Chemical enhancements have been used to overcome this problem (Blaylock et al., 1997; Huang et al., 1997; Ebbs and Kochian, 1997; Wu et al., 1999; Epstein et al., 1999). For further use of the harvested plants, a life cycle analysis of the phytoextracted metal needs to be done with an understanding how they are partitioned within the plant parts.

It is seen that many oil bearing crops have potential to phytoremediate (Shi and Cai, 2009). However they vary in the rate at which they absorb an available metal ion and also in the manner by which they distribute the metals ion into plant parts. Related literature on bioaccumulation and its distribution by commonly cultivated seasonal oil crops are presented in table 5. Important findings for selected crops are highlighted below. 


\subsection{Helianthus annuus L (Sunflower)}

In Lin et al., (2003) studied the accumulation of copper by roots, hypocotyls, cotyledons and leaves of sunflower (Helianthus annuus L.) at different $\mathrm{Cu}^{2+}$ concentration. The roots of plants exposed to $63.55 \mathrm{mg} / \mathrm{L} \mathrm{Cu}^{2+}$ accumulated a large amount of $\mathrm{Cu}^{2+}(1070 \mu \mathrm{g} / \mathrm{g}$ on dry weight basis), the $\mathrm{Cu}^{2+}$ level being approximately 25 fold higher than that for control. The $\mathrm{Cu}^{2+}$ contents in roots treated with $6.36 \mathrm{mg} / \mathrm{L}$ and $0.64 \mathrm{mg} / \mathrm{L} \mathrm{Cu}^{2+}$ were respectively about 3.3 and 2.6 fold higher than the control. Thus, the $\mathrm{Cu}^{2+}$ level of the roots exposed to $63.55 \mathrm{mg} / \mathrm{L} \mathrm{Cu}^{2+}$ was approximately 7.7 and 9.8 fold respectively, in comparison with the roots of plants grown in $6.36 \mathrm{mg} / \mathrm{L}$ and $0.64 \mathrm{mg} / \mathrm{L} \mathrm{Cu}^{2+}$. At $63.55 \mathrm{mg} / \mathrm{L} \mathrm{Cu}^{2+}$, the $\mathrm{Cu}$ accumulated mainly in the roots (about 73\%). However, the $\mathrm{Cu}^{2+}$ concentration in the roots was less than that of the above parts of seedlings in treated groups with 0.64-6.36 $\mathrm{mg} / \mathrm{L} \mathrm{Cu}^{2+} . \mathrm{Cu}^{2+}$ is required by biological systems as a structural and catalytic enzyme component and in the soil. At high concentration $\mathrm{Cu}^{2+}$ can be a stress factor, causing physiological responses that can decrease the vigour of the plants and inhibit plant growth (Ouzounidou, 1994). Thus, it is useful for growth at low concentration but tends to remain in roots at higher concentration. The formation of phytochelatins and metallathionein like proteins induced by $\mathrm{Cu}$ may be related to the detoxification of the metal as in the case of cadmium and zinc stress (Lin et al., 2003). Iwasaki et al. (1990) indicated that at a high supply of $\mathrm{Cu}$, nearly $60 \%$ the total $\mathrm{Cu}$ in roots may be bound to the cell wall fraction and the cell wall-plasma membrane interface. $H$. annuus has potential ability to accumulate $\mathrm{Cu}$ without being overly sensitive to $\mathrm{Cu}$ toxicity. It is $\mathrm{Cu}$ tolerant possibly because the transportation between root to shoot becomes restricted.

Ahmad et al., (2011) showed the phytotoxic effects of varying levels of nickel ion (0, 10, 20, 30, and $40 \mathrm{mg} / \mathrm{L}$ ) on growth, yield and accumulation of macro and micro-nutrients in leaves and achenes of sunflower (Helianthus annuus L.). A marked reduction in root and shoot of fresh biomass was recorded at higher $\mathrm{Ni}$ ion levels. The maximum reduction in all parameters was observed at the maximum level of nickel ion $(40 \mathrm{mg} / \mathrm{L})$ where almost all parameters were reduced more than $50 \%$ of those of control plants. 
A study carried by Singh et al, 2004 showed that an increasing ratio of tannery sludge amendments caused a progressive increase in the accumulation of metal ions ( $\mathrm{Cr}, \mathrm{Fe}, \mathrm{Zn}$ and $\mathrm{Mn}$ ) in the roots, shoots and leaves of the plant of $H$. annuus at all the exposure periods. But the magnitude and relative distribution of various metals differed. Accumulation of all the metals was found maximum in the roots followed by the shoots and leaves. The translocation of $\mathrm{Cr}$ from roots to aerial parts was found least among all the metals tested. The overall comparison of the data showed that the accumulation of Fe was the highest and accumulation of Zn was minimum among all the metals accumulated in different parts of the plant. At 100\% tannery sludge after 90d, the metal accumulation was in the order $\mathrm{Fe}>\mathrm{Cr}>\mathrm{Mn}>\mathrm{Zn}$. The accumulation of all metals (Fe, Mn and $\mathrm{Zn}$ ) the metal being higher in seed coat than seed. Specifically, $\mathrm{Cr}$ accumulated was found below detection limit in seeds of the plant grown on all the sludge amendments. The oil content of $H$. annuus increased up to $35 \%$ tannery sludge, with the maximum increase of $16 \%$ at $25 \%$ sludge amendment, compared to control. Beyond 35\% tannery sludge it decreased. The maximum decrease of $28 \%$ was registered at $100 \%$ tannery sludge as compared to control.

The analysis of the data showed that ions of Fe accumulated more effectively in the plants of $H$. annuus in comparison to $\mathrm{Cr}, \mathrm{Zn}$ and $\mathrm{Mn}$. The observed differences in the metal accumulation in the different parts of $H$. annuus suggest different cellular mechanism of bioaccumulation of metals and its translocation. The availability and bioaccumulation of metal is governed by several environmental factors viz. organic chelators, humic substances, presence of other metals, salinity and other environmental factors. The high accumulation of metals ( $\mathrm{Cr}, \mathrm{Fe}, \mathrm{Zn}$ and $\mathrm{Mn}$ ) particularly in the root tissues of $H$. annuus may be due to complexation of metals with the sulphydryl groups resulting in less translocation of metals to upper part of the plant, which vary from one metal to another. The results indicate usefulness of the plant for remediating of metals from the contaminated site However, extensive trials are prerequisite to find out a proper combination of tannery sludge with each type of soil. Care should be taken to assess the level of metals in terms of seed use (Singh et al , 2004). 
Andaleeb et al (2008) also showed Cr ion was significantly absorbed by roots but its transport to other parts of plants was slow, and uptake in seeds was much lower than in roots and shoots.

Other studies on $H$. annuus also show that it is effective in the ion removal of lead, uranium and plutonium (Kumar et al., 1995; Glass, 1998; Lee et al., 2002). Certain varieties of sunflower were also identified as the most efficient plants for rhizofiltration (Dushenkov et al., 1995; Brooks and Robinson, 1998).

Davies, J. et al., (2001) studied the ability of the arbuscular mycorrhizal fungus (AM), Glomus intraradices, to enhance $\mathrm{Cr}$ ion uptake and plant tolerance and of sunflower (Helianthus annuus L.). Chromium accumulation was greatest in roots, intermediate in shoots and leaves, and lowest in flowers. Greater phytoextraction would be expected if roots were harvested from plants grown in field sites. Interestingly, shoots of AM sunflower accumulated considerably more $\mathrm{Cr}$ ion (1268 $\mu \mathrm{g} / \mathrm{g}$ dry matter basis) than reported in Brassica (80 $\mu \mathrm{g} / \mathrm{g}$ dry matter basis) or Thlaspi (89 $\mu \mathrm{g} / \mathrm{g}$ dry matter basis) (Salt et al. 1995). Chromium is reported to toxic to agronomic plants at about 0.5 to $5.0 \mu \mathrm{gmL}^{-}$ ${ }^{1}$ in nutrient solution and to 5 to $100 \mu \mathrm{g} / \mathrm{g}$ in soil (Hossner 1996). Helianthus annus L. specifically seems to be higher $\mathrm{Cr}$ accumulator. Greater $\mathrm{Cr}$ accumulation occurred with the more soluble $\mathrm{Cr}^{6+}$ than $\mathrm{Cr}^{3+}$. The low solubility of $\mathrm{Cr}^{3+}$ and strong retention on soil surfaces limits its bioavailability and mobility in soil and water (James 1996).

\subsection{Brassica juncea (Indian Mustard)}

Brassica juncea has considerable ability to remove $\mathrm{Pb}$ ion from solutions and accumulate it. The effects of different concentrations of lead nitrate (2.07-207.2 mg/L) on root, hypocotyl and shoot growth of Indian mustard (Brassica juncea var. Megarrhiza) was studied (Liu et al., 2000). Root growth decreased progressively with increasing concentration of $\mathrm{Pb}^{2+}$ in solutions. The seedlings exposed to $207.2 \mathrm{mg} / \mathrm{L} \mathrm{Pb}^{2+}$ exhibited substantial growth reduction and produced chlorosis. The Pb content in roots of $B$. juncea increased with increasing solution concentration of $\mathrm{Pb}^{2+}$. The amount of $\mathrm{Pb}$ in roots of plants treated with 20.72, 207.2 and $2.07 \mathrm{mg} / \mathrm{L} \mathrm{Pb}^{2+}$ were 184-, 37- and 6-fold, 
respectively, greater than that of roots of the control plant $(86.8 \mu \mathrm{g} / \mathrm{g}$ on dry weight basis). Thus beyond $20.72 \mathrm{mg} / \mathrm{L}$ metal ion concentration $\mathrm{Pb}$ is inhibitory to the growth of plant. However, the plants transported and concentrated only a small amount of $\mathrm{Pb}$ in their hypocotyls and shoots, except for the group treated with $207.2 \mathrm{mg} / \mathrm{L} \mathrm{Pb}^{2+}$.

Chandra et al, 2009 studied the accumulation and distribution of various toxic metal ions $(\mathrm{Cu}, \mathrm{Cd}, \mathrm{Cr}, \mathrm{Zn}, \mathrm{Fe}, \mathrm{Ni}, \mathrm{Mn}$, and $\mathrm{Pb}$ ) and their biochemical effect on wheat and mustard plants irrigated with mixed distillery and tannery effluents. The pattern of metal accumulation was generally root $>$ leaves $>$ seeds for $\mathrm{Cu}$ and $\mathrm{Zn}$, roots $>$ seeds $>$ leaves for $\mathrm{Ni}$, leaves $>$ seeds $\geq$ roots for $\mathrm{Cd}, \mathrm{Cr}$ and $\mathrm{Pb}$, leaves $>$ roots $>$ seeds for $\mathrm{Fe}$ and $\mathrm{Mn}$ in mustard plants. Least accumulation was found in shoots for most of the toxic metals like $\mathrm{Cu}, \mathrm{Zn}, \mathrm{Cr}, \mathrm{Ni}, \mathrm{Fe}$ and $\mathrm{Mn}$.

\subsection{Sesamum indicum (L.)}

A pot experiment was carried out by Gupta and Sinha, (2006) on heavy metal accumulation in the plant of Sesamum indicum (L.) var. T55 grown on soil amended with tannery sludge. The metal ion accumulation after $60 \mathrm{~d}$ of growth of the plant was found in the order of $\mathrm{K}>\mathrm{Na}>\mathrm{Fe}>\mathrm{Zn}>\mathrm{Cr}>\mathrm{Mn}>\mathrm{Cu}>\mathrm{Pb}>\mathrm{Ni}>\mathrm{Cd}$ and its translocation was found less in upper part. The accumulation of toxic metal ions ( $\mathrm{Cr}, \mathrm{Ni}$ and $\mathrm{Cd}$ ) in the plants was found to increase with increase in sludge ratio, in contrast, the accumulation of $\mathrm{Pb}$ ion decreased. In view of growth parameters and metal ion accumulation in the plant, it was observed that lower amendments (25\%) of tannery sludge were found suitable for the phytoremediation by most of the studied metals.

Effect of organic waste compost on sesame was studied out by Abdel-Sabour and ElSeoud, (1996). Heavy metal ion contents (Fe, Mn, Zn, Cu, Co, Ni, Cd, Pb) in seeds samples were determined. The maximum levels $\left(\mu \mathrm{g} \mathrm{g}^{-1}\right)$ of tested metals in seeds did not exceed 226 Fe, 12.5 Mn, 81.7 Zn, 23.7 Cu, 3.8 Co, 24.6 Ni, 5.4 Pb and 1.72 Cd, which are below the reported concentrations at which phytotoxicity could occur. 


\subsection{Ricinus communis $L$ (Castor)}

Studies by Shi and Cai (2009) on cadmium tolerance and accumulation in eight potential energy crops by phytoremediation have shown that all plants had moderate tolerance to cadmium toxicity, with four [i.e., hemp (Cannabis sativa), flax (Linum usitatissimum), castor (Ricinus communis) and peanut (Arachis hypogaea)] being more tolerant than the others. The roots of peanut and hemp had high bioconcentration factors (BCF>1000), while in flax shoots had a higher concentration of $\mathrm{Cd}(>100 \mathrm{mg} / \mathrm{kg})$. These results demonstrate that it is possible to grow energy crops on Cd-contaminated soil. Hemp, flax and peanut are good candidates for phytoremediation.

Huang et. al., (2011) reported the bioconcentration factor (BCFs) of castor genotypes for DDTs varied from 0.10 to 0.42 in leaf, 0.09 to 1.06 in stem, and 31.34 to 65.33 in root The average BCFs of castor genotypes for Cd was 0.43, 0.80 and 13.30 in leaf, stem and root, respectively, higher than the values reported by Shi and Cai (2009). These results confirmed that the castor plant has an exceptional capacity for the accumulation of DDTs, particularly in root when grown in contaminated soils. Translocation factor (TF) is another indicator reflecting pollutant transfer to shoots from the roots. The calculated DDTs TF values for different castor genotypes were generally $<1.0$, ranging from 0.002 to 0.0109 for leaf and from 0.0027 to 0.024 for stem. This result implied that most DDTs absorbed by castor plant was retained in roots with a small portion being translocated to the shoots.

Mo et. al., (2008) have suggested that, apart from the biological processes of DDTs entering plant roots, it is likely that some DDTs can remain adsorbed on the external root surface even though the roots are rinsed thoroughly, and consequently the DDTs concentration in the roots is overestimated. The high DDTs content in castor root might be also related to its vitality with strong stretch ability to explore the soil. Castor had a Cd TF value of 0.0333 for leaf and 0.0620 for stem, similar to the observations by Shi and Cai (2009). Root DDTs and Cd respectively accounted for 95.6-99.4\% and 82.1-93.7\% of total plant uptake, due to higher concentrations of DDTs and Cd in the roots and comparable root biomass to the shoot. 


\subsection{Rapeseed (Brassica napus)}

Zinc (Zn) is a necessary element for plants, but excess $\mathrm{Zn}$ can be detrimental. To investigate Zn toxicity. Wang et. al, (2009) used rapeseed (Brassica napus) seedlings were treated with 4.58-66.69 mg/L Zn for $7 \mathrm{~d}$. Inhibition of plant growth along with root damage, chlorosis and decreased chlorophyll ( $\mathrm{a}$ and $\mathrm{b}$ ) content in newly expanded leaves (the second and third leaves formed following cotyledons) were found under $\mathrm{Zn}$ stress. The $\mathrm{Zn}$ content increased in plants under external $\mathrm{Zn}$ stress, while concentrations of phosphorus, copper, iron, manganese and magnesium reduced significantly, especially in roots.

Ghnaya et. al, (2009) studied out the variable behaviour of the four rapeseed cultivars in reaction to metallic stress, indicating a cultivar effect. The nature of the response to stress of each cultivar depended on the metal. $\mathrm{ZnSO}_{4}$ and $\mathrm{CdCl}_{2}$ application led to a variation of the biomass, growth, chlorophyll and carotenoid content, and metal accumulation. Some cultivars (Cossair and Pactol) were sensitive to metallic stress while others were resistant (Jumbo and Drakkar). Under the conditions of study, the two of the cultivars (Jumbo and Drakkar) seemed more efficient in phytoextraction since both showed a significant increase in $\mathrm{Zn}$ and $\mathrm{Cd}$ accumulation in all parts of the plants. When compared to the control, they accumulated nearly the double at the level of the aerial parts $(\mathrm{L})$ and $(\mathrm{S}+\mathrm{P})$.

\subsection{Discussion on Bioaccumulation}

The above studies show that the following: the oil bearing plants are generally tolerant to toxic metals and accumulate metals in the order $\mathrm{Fe}>\mathrm{Mn}, \mathrm{Cr}, \mathrm{Zn}>\mathrm{Cu}>\mathrm{Pb}>\mathrm{Ni}>\mathrm{Cd}$. The high absorption of Fe, Mn and $\mathrm{Zn}$ could be attributed to these being micronutrients. However many of the plants also accumulate high level of Cr. Metal accumulation is highest in roots in many cases. Shu et al. (2002) showed that roots accumulated much higher concentrations of heavy metals than shoots. However, in some cases Fe, Mn and $\mathrm{Cr}$ accumulated more in leaves. Generally, different plant parts accumulate different amounts of heavy metals, in the order root or leaves $>$ flower buds $>$ fruit. This may be due to the fact that roots are the parts which come into direct contact with the toxic metals present in the soil from where the metal has to be transported. Metal may be immobilized 
in root cells by an exclusion mechanism (Baker, 1987) and root may act as a barried to transfer (Jones and Clement, 1972). Metal exclusion is the avoidance of absorption and the restriction of translocation to the shoots. On the other hand, metal accumulation is an extreme type of physiological response whereby plants absorb and accumulate high concentrations of metals (Dahmani-Muller et al., 2000, Smical et al., 2008).

But, depending on the nature and metal concentration, metal also gets translocated to leaves from root. Generally, it is not reaching the seed or fruit. However, the uptake and accumulation of metals by different plant species depend on several factors (Bingham et al., 1975; Dowdy et al., 1978). It varies with cultivar, presence of environmental factors, chelating factor etc. Plants absorb and accumulate metals from the soil and water, which up to certain level are essential for their growth and development and cannot be substituted by other elements, as they are specific to many biochemical processes (Langille and MacLean, 1976).

\section{Conclusion}

The above review shows that the oil bearing plants can be used for generating energy not only in terms of seeds and oil but also in terms of their biomass. The oil can also serve as chemical feedstock. While the oil yield by these crops is comparable to tree based oil production, additionally they yield biomass. Plants like castor produce biomass residues comparable to biomass from high yielding perennial grasses. Irrigation increases the productivity of oil bearing crops 2 or 3 times. Since waste water has nutrients, irrigation with this will increase yield of both seeds and biomass by many folds. The total energy output per hectare of oil bearing plants like castor can be further enhanced by irrigation and appropriate agronomics inputs. Thus in arid zones non-edible plants like castor can be raised on wastelands with waste water irrigation for getting high amounts of oil and biomass. Many of these plants phytoremediate the soil. They bioaccumulate various metals from soil and also exhibit tolerance to toxicity. Also, the metals accumulated essentially remain in the roots and are not translocated to seed and oil. 


\section{Acknowledgment}

Authors are grateful for the financial support for the work through EPSRC, UK (grant reference EP/E044360/1) and RC-UK DST (EP/G021937/1) Science Bridge Project funded projects. One of author Mamta Tandon is thankful to University Grant Commission (UGC), India, for the award of Post Doctorate Fellowship. 


\section{References:}

Abdel-Sabour, M.F. and E1-Seoud, M.A.A. (1996), "Effects of organic-waste compost addition on sesame growth, yield and chemical composition”. Agriculture, Ecosystems and Environment, Vol. 60, pp. 157-164.

Ahmad, M.S.A., Ashrafa, M. and Hussain, M. (2011). "Phytotoxic effects of nickel on yield and concentration of macro- and micro-nutrients in sunflower (Helianthus annuus L.) achenes”. Journal of Hazardous Materials, Vol. 185, pp. 1295-1303.

Akbari, P., Ghalavand, A., Modarres Sanavy, A.M. and Alikhani, M.A. (2011), "The effect of Biofertilizers, nitrogen fertilizer and farmyard manure on grain yield and seed quality of sunflower (Helianthus annus L.)”. J. of Agri. Tech., Vol. 7 No. 1, pp. 173-184.

Andaleeb, F., Zia, M.A., Ashraf, M. and Khalid, Z.M. (2008). "Effect of chromium on growth attributes in sunflower (Helianthus annuus L.)”. Journal of Environmental Sciences, Vol. 20, pp. 1475-1480.

Baker, A.J.M. (1987), “Metal tolerance”. New Phytol, Vol. 106, pp. 93-111.

Bender, M. (2000), "Potential conversion of biomass in the production of synthetic organics”. Resources Conservation and Recycling, Vol. 30, pp 49-58.

Bingham F.T., Page A.L., Mahler R.J. and Ganje T.J. (1975), "Growth and cadmium accumulation of plants grown on a soil treated with cadmium-enriched sewage sludge”. $J$ Environ Qual, Vol. 4, pp. 207-211.

Blaylock, M.J., Salt, D.E., Dushenkov, S., Zakharova, O., Gussman, C., Kapulnik, Y., Ensley, B.D. and Raskin, I. (1997), “Enhanced accumulation of Pb in Indian mustard by soil-applied chelating agents”. Environ. Sci. Technol, Vol. 31, pp. 860-865. 
Borjesson, P. and Goran, B. (2006), "The prospects for willow plantations for waste water treatment in Sweden”. Biomass and Bioenergy, Vol. 30, pp. 428-438.

Brooks, R.R. and Robinson, B.H. (1998), “Aquatic phytoremediation by accumulator plants”, in: Brooks, R.R. (Ed.), Plants that Hyperaccumulate Heavy metals: Their Role in Phytoremediation, Microbiology, Archaeology, Mineral exploration and Phytomining. CAB International, New York, NY, pp. 203-266.

Chandra, R., Bharagava, R.N., Yadav, S. and Mohan, D. (2009). "Accumulation and distribution of toxic metals in wheat (Triticum aestivum L.) and Indian mustard (Brassica campestris L.) irrigated with distillery and tannery effluents”. Journal of Hazardous Materials, Vol. 162, pp. 1514-1521.

Dahmani-Muller, H., Van, O.F., Gelie, B. and Balabane, M. (2000) "Strategies of heavy metal uptake by three plant species growing near a metal smelter”. New Phytol, Vol. 109, pp. 231-238.

Davies, F.T., Puryear, J.J.D., Newton, R.J., Egilla, J.N. and Grossi, J.A.S. (2001). "Mycorrhizal fungi enhance accumulation and tolerance of chromium in sunflower (Helianthus annuus)”. J. Plant Physiol, Vol. 158, pp. 777-786.

Demirbas, M.F. (2006), “Current technologies for biomass conversion into chemicals and fuels”. Energy Source Part A, Vol. 28, pp 1181-8,

Dowdy, R.H., Larson, W.E., Titrud, J.M. and Latterell, J.J. (1978). “Growth and metal uptake of snap beans growth on sewage sludge amended soil: A four year study”. $J$. Environ. Qual, Vol. 7, pp. 252-257.

Dushenkov, V., Kumar, P.B.A.N., Motto, H. and Raskin, I. (1995), “Rhizofiltration: the use of plants to remove heavy metals from aqueous streams”. Environ. Sci. Tech, Vol. 29, pp. 1239-1245. 
Ebbs, S.D. and Kochian, L.V. (1997). “Toxicity of zinc and copper to Brassica species: implications for phytoremediation”. J. Environ. Qual, Vol. 26, pp. 776-781.

Epstein, A.L., Gussman, C.D., Blaylock, M.J., Yermiyahu, U., Huang, J.W., Kapulnik, Y. and Orser, C.S. (1999). "EDTA and Pb-EDTA accumulation in Brassica juncea grown in Pb-amended soil. Plant and Soil 208, 87-94.

Fernando, S., Adhikari, S., Chadrapal, c. and Murali, N. (2006). "Biorefineries: Current status challenges and future direction”. Energy Fuel, pp 1727-37.

Ghnaya, A.B., Charles, G., Hourmant, A., Hamida, J.B. and Branchard. (2009), "M. Physiological behaviour of four rapeseed cultivar (Brassica napus L.) submitted to metal stress”. C. R. Biologies, Vol. 332, pp. 363-370.

Glass, D.J. (1998). "Phytoremediation technologies and application”, In: The 1998 United States Market for Phytoremediation, D. Glass Associates Inc., Needham, MA, pp. 3-16.

Grigoriou, A.H. and Ntalos, G.A. (2001). "The potential use of Ricinus communis L. (Castor) stalks as a lignocellulosic resource for particleboards”. Industrial Crops and Products, Vol. 13, pp. 209-218.

Gupta, A.K. and Sinha, S. (2006). "Chemical fractionation and heavy metal accumulation in the plant of Sesamum indicum (L.) var. T55 grown on soil amended with tannery sludge: Selection of single extractants”. Chemosphere, Vol. 64, pp. 161-173.

Hornung, A., Apfelbacher, A. and Sagi, S. (2011). "Intermediate pyrolysis: A sustainable biomass-to-energy concept - Biothermal valorization of biomass (BtVB) process”. J. of Sci. \& Ind. Res., Vol. 70, pp. 664-667. 
Hossain, A.K., Thorpe, R., Critoph, R.E. and Davies, P.A. (2011). "Development of a small-scale trigeneration plant based on a CI engine fuelled by neat non-edible plant oil”. J. of Sci. \& Ind. Res., Vol. 70, pp. 688-693.

Hossner, L.R. (1996). "Phytoaccumulation of selected heavy metals, uranium, and plutonium in plant systems”. Quarterly Progress Report. Nov 1995-Jan 1996. Project UTA96-0043, Dept Soil Crops, Texas A\&M Univ, College Station, Texas pp. 77843.

Huang, H., Yu, N., Wang, L., Gupta, D.K., He, Z., Wang, K., Zhu, Z., Yan, X., Li, T. and Yang, X. (2011). “The phytoremediation potential of bioenergy crop Ricinus communis for DDTs and cadmium co-contaminated soil”. Bioresource Technology, Vol. 102, pp. 11034-11038.

Huang, J.W., Chen, J.J., Berti, W.R. and Cunningham, S.D. (1997). "Phytoremediation of lead-contaminated soils: role of synthetic chelates in lead phytoextraction”. Environ. Sci. Technol., Vol. 31, pp. 800-805.

Iwasaki, K., Sakurai, K. and Takahashi, E. (1990). “Copper binding by the root cell walls of Italian ryegrass and red clover”. Soil Sci., Plant Nutr. (Tokyo), Vol. 36, pp. 431-440.

James. B.R (1996). “The challenge of remediating chromium-contaminated soil”. J. Environ. Sci., Vol. 30, pp. 248-251.

Jones, L.H.P. and Clement, C.R. (1972). "Lead uptake by plants and its significance for animals”. In “Lead in the Environment”,(Ed. Hepple P.), Applied Science Publishers, Barking, pp. 29-33.

Joint FAO/WHO Expert Committee on Food Additives (JECFA), 2006. http://www.fao.org/fileadmin/templates/agns/pdf/jecfa/2002-0910_Explanatory_note_Heavy_Metals.pdf 
Kumar, P.B.A.N., Dushenkov, V., Motto, H. and Raskin, I. (1995). "Phytoextraction-the use of plants to remove heavy metals from soils”. Environ. Sci. Tech., Vol. 29, pp. 12321238.

Langille, W.M. and MacLean, K.S. (1976). "Some essential nutrient elements in forest plants as related to species, plant part, season and location”. Plant Soil, Vol. 45, pp. 1726.

Lee, J.H., Hossner, L.R., Attrep Jr., M. and Kung, K.S. (2002). “Uptake and translocation of plutonium in two plant species using hydroponics”. Environ. Pollut., Vol. 117, pp. 6168.

Lewandowski, I., Scurlock, J.M.O., Lindvall, E. and Christou, M. (2003). “The development and current status of perennial rhizomatous grasses as energy crops in the US and Europe”. Biomass and Bioenergy, Vol. 25, pp. 335-361.

Lima, R.L.S., Severino, L.S., Sampaio, L.R., Sofiatti, V., Gomes, J.A. and Beltrao, N.E.M. (2011). "Blends of castor meal and castor husks for optimized use as organic fertilizer”. Industrial Crops and Products, Vol. 33, pp. 364-368.

Lin, J. Jiang, W. and Liu, D. (2003). “Accumulation of copper by roots, hypocotyls, cotyledons and leaves of sunflower (Helianthus annuus L.)”. Bioresource Technology, Vol. 86, pp. 151-155.

Liu, D., Jiang, W., Liu, C., Xin, C. and Hou, W. (2000). "Uptake and accumulation of lead by roots, hypocotyls and shoots of Indian mustard [Brassica juncea (L.)]”. Bioresource Technology, Vol. 71, pp.273-277.

Maobe, M.A.G., Gatebe, E., Gitu, L. and Rotich, H. (2012). "Profile of heavy metals in selected medicinal plants used for the treatment of diabetes, malaria and pneumonia in 
kisii region, Southwest Kenya. Global Journal of Pharmacology, Vol. 6 No. 3, pp. 245251.

McGrath, S.P. (1998). "Phytoextraction for soil remediation”, in: Brooks, R.R. (Ed.), Plants that Hyperaccumulate Heavy Metals, CAB International, Wallingford, UK, pp. 261-287.

McGrath, S.P., Zhao, F.J. and Lombi, E. (2002). "Phytoremediation of metals, metalloids, and radionuclides”. Adv. Agron., Vol. 75, pp. 1-56.

McKendry, P. (2002a). "Energy production from biomass (part 1): Overview of biomass. Bioresource Technology, Vol. 83, pp. 37-46.

McKendry, P. (2002b). "Energy production from biomass (part 2): Conversion Technologies. Bioresource Technology, Vol. 83, pp. 47-54.

Meher, L.C., Vidyasagar, D. and Naik S.N. (2006). "Technical aspects of biodiesel production by transesterification - A review”. Renew Sust Energ Rev, Vol.10, pp. 248268.

Mo, C.H., Cai, Q.Y., Li, H.Q., Zeng, Q.Y., Tang, S.R., Zhao, Y.C. (2008). "Potential of different species for use in removal of DDT from the contaminated soil”. Chemosphere, Vol. 73 No. 1, pp. 120-125.

"National Oilseed and Vegetable Oil Development Board", available at: http:// www.novodboad.com/Publications.htm

Naik, S.N., Goud, V.V., Rout, P.K. and Dalai, A.K. (2010). "Production of first and second generation biofuels: A comprehensive review”. Renewable and Sustainable Energy Reviews, Vol. 14, pp. 578-597. 
Nehnevajova, E., Lyubenova, L., Herzig, R., Schroder, P., Schwitzguebel, J.P. and Schmulling, T. (2012). "Metal accumulation and response of antioxidant enzymes in seedlings and adult sunflower mutants with improved metal removal traits on a metalcontaminated soil”. Environmental and Experimental Botany, Vol. 76, pp. 39- 48.

Ouzounidou, G., (1994). "Root growth and pigment composition in relationship to element uptake in Silene compacta plants treated with copper”. J. Plant Nutr., Vol. 17, pp. 933-943.

Pandey, A., Singh, M., Srivastava, R.K. and Vasudevan, P. (2011). "Pollutant Removal Potential Growth and Nutritional Characteristics of Short Rotation Woody Crops in Grey Water Vegetation Filter System”. J. of Sci. \& Ind. Res., Vol. 70, pp. 610-615.

Pb-amended soil”. Plant and Soil, Vol. 208, pp. 87-94.

Quartacci, M.F., Argilla, A., Baker, A.J.M. and Navari-Izzo, F. (2006). "Phytoextraction of metals from a multiply contaminated soil by Indian mustard”. Chemosphere, Vol. 63, pp. 918-925.

Rajkumar, M., Nagendran, R., Lee, K.J., Lee, W.H. and Kim, S.Z. (2006). “Influence of plant growth promoting bacteria and $\mathrm{Cr}^{6+}$ on the growth of Indian mustard". Chemosphere, Vol. 62, pp. 741-748.

Rajvanshi, A.K, Singh, V. and Nimbkar, N. (2007). "Biofuels-Promise/Prospects”, paper presented at the Conference at National Oilseeds Conference in Hyderabad, 29-31 January 2007, available at: http://www.nariphaltan.org/nari/pdf_files/biofuels.pdf.

Salt, D.E., Blaylock, M., Kumar, N.P.B.A., Dushenkov, V., Ensley, B.D., Chet, I. and Raskin., I. (1995). "Phytoremediation: a novel strategy fro the removal of toxic metals from the environment using plants”. Bio/Technol, Vol. 13, pp. 468-474. 
Salt, D.E., Smith, R.D. and Raskin, I. (1998). "Phytoremediation. Ann. Rev. Plant Physiol”. Plant Mol. Biol., Vol. 49, pp. 643-668.

Santamaria, P., Elia, A., Serio, F. and Todaro, E. (1999). “A survey of nitrate, metals and oxalate content in retail fresh vegetables”. J Sci Food Agric, Vol. 79, pp. 1882-1888.

Shi, G. and Cai, Q. (2009). “Cadmium tolerance and accumulation in eight potential energy crops”. Biotechnology Advances, Vol. 27, pp. 555-561.

Shu, W.S., Ye, Z.H., Lan, C.Y., Zhang, Z.Q. and Wong, M.H. (2000). "Lead, Zinc and Copper accumulation and tolerance in population of Paspalum distichum and Cynodon dactylon”. Environ. Polln., Vol. 120, pp. 445-453.

Singh, S., Saxena, R., Pandey, K., Bhatt, K. and Sinha, S. (2004). "Response of antioxidants in sunflower (Helianthus annuus L.) grown on different amendments of tannery sludge: its metal accumulation potential”. Chemosphere, Vol. 57, pp. 1663-1673.

Smical, A., Hotea, V., Oros, V., Juhasz, J. and Pop E. (2008). "Studies on transfer and bioaccumulation of heavy metals from soil into lettuce”. Environ Eng Manag J, Vol. 7, pp. 609-615.

Thapliyal, A., Vasudevan, P., Dastidar, M.G., Tandon, M., Sen, P.K. and Mishra, S. (2011). "Growth of Tree Saplings of Neem (Azadirachta indica Jues) Under Fertigation with Untreated and Treated Domestic Waste water”. J. of Sci. \& Ind. Res., Vol. 70, pp. 616-621.

Toky, O.P., Black, D.R., Harris, PJC, Vasudevan P. and Davies P.A. (2011). "Biomass Production in Short Rotation Effluent Irrigated Plantation in North-West India”. J. of Sci. \& Ind. Res., Vol. 70, pp. 601-609. 
Vasudevan, P., Thapliyal, A., Srivastava, R.K., Pandey, A., Dastidar, M.G., and Davies, P. (2010). “Fertigation Potential of Domestic Waste water for Tree Plantations”. J. of Sci. \& Ind. Res., Vol. 69, pp. 146-150.

Vwioko, D.E., Anoliefo, G. and Fashemi, S.D. (2006). "Metal Concentration In Plant Tissues of Ricinus Communis L. (Castor Oil) Grown In Soil Contaminated With Spent Lubricating Oil”. J. Appl. Sci. Environ. Mgt., Vol. 10 No. 3, pp. 127 - 134.

Wang, C., Zhang, S.H., Wang, P.F., Hou, J., Zhang, W.J., Li, W. and Lin, Z.P. (2009). "The effect of excess $\mathrm{Zn}$ on mineral nutrition and antioxidative response in rapeseed seedlings”. Chemosphere, Vol. 75, pp. 1468-1476.

WHO., 2005. Quality Control Methods for Medicinal Plant Materials, Revised, Geneva.

Wu, J., Hsu, F.C. and Cunningham, S.D. (1999). “Chelate-assisted Pb phytoextraction: $\mathrm{Pb}$ availability, uptake, and translocation constraints”. Environ. Sci. Techno., Vol. 33, pp. 1898-1904.

Wu, L.H., Luo, Y.M., Xing, X.R. and Christie, P. (2004). "EDTA-enhanced phytoremediation of heavy metal contaminated soil with Indian mustard and associated potential leaching risk. Agriculture”. Ecosystems and Environment, Vol. 102, pp. 307318. 
Tables:

Table 1: Yield of seed, oil and crop residue for different oilseed crops under rainfed and irrigated conditions in India

Table 2: Yield of selected tree-borne oil seeds and oil (National Oilseed and Vegetable Oil Development Board)*

Table 3: Comparison of energy potential of perennial grasses with seasonal oil seed crops

Table 4: Total energy potential from oil seed crops under rainfed and irrigated condition in India

Table 5: Bioaccumulation of metal ions and phytoremediation of soil by seasonal oil bearing plants 
Table 1: Yield of seed, oil and crop residue for different oilseed crops under rainfed and irrigated conditions in India

\begin{tabular}{|c|c|c|c|c|c|c|}
\hline S.No. & Crops & $\begin{array}{c}\text { Rainfed } \\
\text { Condition } \\
\text { Potential } \\
\text { seed yield } \\
\text { per season } \\
\text { (kg/ha)* }\end{array}$ & $\begin{array}{c}\text { Irrigated } \\
\text { Condition } \\
\text { Potential } \\
\text { seed yield } \\
\text { per season } \\
\text { (kg/ha)* }\end{array}$ & $\begin{array}{c}\text { \% oil } \\
\text { Content }\end{array}$ & $\begin{array}{c}\text { Crop } \\
\text { Residue to } \\
\text { Seed Ratio }\end{array}$ & $\begin{array}{c}\text { Ratio of } \\
\text { yield } \\
\text { under } \\
\text { irrigated } \\
\text { to yield } \\
\text { under } \\
\text { rainfed** }\end{array}$ \\
\hline 1 & Castor & 1267 & 3000 & 49 & 3.0 & 2.3 \\
\hline 2 & Groundnut & 1500 & 2186 & 50 & 2.0 & 1.4 \\
\hline 3 & Mustard & 613 & 1385 & 41 & 6.1 & 2.2 \\
\hline 4 & Sunflower & 1028 & 1691 & 39 & 3.2 & 1.6 \\
\hline 5 & Safflower & 1034 & 1688 & 30 & 3.0 & 1.6 \\
\hline 6 & Rapeseed & 898 & 1027 & 41 & 4.9 & 1.1 \\
\hline 7 & Linseed & 861 & 1097 & 37 & 1.9 & 1.2 \\
\hline 8 & Sesame & 516 & 616 & 50 & 2.7 & 1.1 \\
\hline
\end{tabular}

*Rajvanshi et al., 2007

** Increase in total yield for seed and biomass on irrigation 
Table 2: Yield of selected tree-borne oil seeds and oil (National Oilseed and Vegetable Oil Development Board)*

\begin{tabular}{|c|l|c|c|c|c|c|}
\hline S.No. & Crops & $\begin{array}{c}\text { Maturity } \\
\text { of tree for } \\
\text { seed yield }\end{array}$ & $\begin{array}{c}\text { Seed Yield } \\
\text { kg/tree on } \\
\text { maturity }\end{array}$ & $\begin{array}{c}\text { Potential } \\
\text { seed** } \\
\text { yield } \\
\text { (kg/ha in a } \\
\text { year) }\end{array}$ & $\begin{array}{c}\text { Oil } \\
\text { Content } \\
\text { (\%) }\end{array}$ & $\begin{array}{c}\text { Average } \\
\text { Oil Yield } \\
\text { (kg/ha in a } \\
\text { year) }\end{array}$ \\
\hline 1 & Jatropha & 5 & $1-2$ & $2500-4000$ & $\begin{array}{c}30-40 \\
\text { (avg. 35) }\end{array}$ & $875-1400$ \\
\hline 2 & $\begin{array}{l}\text { Karanja } \\
\text { (Pongamia } \\
\text { piñata })\end{array}$ & 5 & $6-18$ & $2400-7200$ & $\begin{array}{c}27-39 \\
\text { (avg. 33) }\end{array}$ & $792-2376$ \\
\hline 3 & $\begin{array}{l}\text { Neem } \\
\text { (Azadirachta } \\
\text { indica) }\end{array}$ & $3-5$ & $1.5-12.19$ & $480-3900$ & $\begin{array}{c}30-50 \\
\text { (avg. 40) }\end{array}$ & $192-1560$ \\
\hline 4 & Simarouba & 5 & $0.28-3.33$ & $100-1200$ & 40 & $40-480$ \\
\hline 5 & Jojoba & 4 & $0.06-0.50$ & $100-900$ & 50 & $50-450$ \\
\hline
\end{tabular}

*www.novodboad.com/Publications.htm

**This is an estimate of the potential of seed yield increase with age of plant. The yield per hectare will also depend on the density of plantation. 
Table 3: Comparison of energy potential of perennial grasses with seasonal oil seed crops

\begin{tabular}{|c|c|c|c|c|c|}
\hline S.No. & $\begin{array}{l}\text { Type of } \\
\text { Energy Crop }\end{array}$ & Plant & $\begin{array}{l}\text { Average oil yield/ } \\
\text { season (kg/ha) }\end{array}$ & $\begin{array}{l}\text { Biomass } \\
\text { Yield } \\
\text { (kg/ha) }\end{array}$ & $\begin{array}{c}\text { Total } \\
\text { Energy } \\
\text { Production/ } \\
\text { Season } \\
\text { (MJ/ha) } \\
\text { X 10 } \text { 10 }^{3}\end{array}$ \\
\hline \multirow[t]{4}{*}{1} & \multirow[t]{4}{*}{ Grasses } & $\begin{array}{l}\text { Switchgrass } \\
\text { (Panicum } \\
\text { virgatum) } \\
\end{array}$ & - & $5000-23000^{*}$ & $75-345$ \\
\hline & & Miscanthus spp. & - & $5000-44000 *$ & $75-660$ \\
\hline & & $\begin{array}{l}\text { Reed Canary } \\
\text { Grass (Phalaris } \\
\text { arundinacea) }\end{array}$ & - & 7000-13000* & 105-195 \\
\hline & & $\begin{array}{l}\text { Giant Reed } \\
\text { (Arudo donax) }\end{array}$ & - & $3000-37000 *$ & $45-555$ \\
\hline \multirow[t]{4}{*}{2} & \multirow{4}{*}{$\begin{array}{l}\text { Seasonal Oil } \\
\text { Seed Crop }\end{array}$} & Castor & $621-1470 * *$ & $3801-9000 * *$ & $82-196$ \\
\hline & & Groundnut & $750-1093 * *$ & $3045-4438^{* *}$ & $77-112$ \\
\hline & & Sunflower & $401-659 * *$ & $3255-5355 * *$ & $66-108$ \\
\hline & & Mustard & $251-568^{* *}$ & 3766-8508** & $67-151$ \\
\hline
\end{tabular}

*Lewandowski et al., 2003)

**Rajvanshi et al., 2007) 
Table 4: Total energy potential* from oil seed crops under rainfed and irrigated condition in India

\begin{tabular}{|c|c|c|c|c|c|}
\hline S.No. & Crops & $\begin{array}{c}\text { Energy production } \\
\text { from oil/season } \\
\text { (MJ/ha) X 10 } \\
\text { (under rainfed } \\
\text { condition) }\end{array}$ & $\begin{array}{c}\text { Energy from crop } \\
\text { residues/ } \\
\text { season } \\
(\mathrm{MJ} / \mathrm{ha}) \\
\mathrm{X} \mathrm{10} \mathbf{1 0}^{3} \\
\text { (under rainfed } \\
\text { condition) }\end{array}$ & $\begin{array}{c}\text { Total energy } \\
\text { production/ } \\
\text { season } \\
(\mathrm{MJ} / \mathrm{ha}) \\
\mathrm{X} \mathrm{10} \\
\text { Under } \\
\text { Rainfed }\end{array}$ & $\begin{array}{c}\text { Total } \\
\text { energy } \\
\text { production } \\
\text { /season } \\
\text { (MJ/ha) } \\
\text { X 10 } \\
\text { under } \\
\text { Irrigated }\end{array}$ \\
\hline 1 & Castor & 25.8 & 57.0 & 82.0 & 196.1 \\
\hline 2 & Groundnut & 31.2 & 45.7 & 76.9 & 112.1 \\
\hline 3 & Mustard & 10.4 & 56.5 & 66.9 & 151.2 \\
\hline 4 & Sunflower & 16.7 & 48.8 & 65.5 & 107.7 \\
\hline 5 & Safflower & 12.9 & 46.5 & 59.4 & 97.0 \\
\hline 6 & Rapeseed & 15.3 & 65.8 & 73.1 & 92.7 \\
\hline 7 & Linseed & 13.3 & 24.0 & 37.3 & 47.4 \\
\hline 8 & Sesame & 10.7 & 20.9 & 31.6 & 37.8 \\
\hline
\end{tabular}

*Total energy potential has been estimated as the sum of the "heating values" for direct combustion of the oil and bio residue. This would become higher if the energy potential of oil cake is added. 
Table 5: Bioaccumulation of metal ions and phytoremediation of soil by seasonal oil bearing plants

\begin{tabular}{|c|c|c|c|c|c|}
\hline S.No. & $\begin{array}{c}\text { Name of } \\
\text { Plant }\end{array}$ & Type of Water & $\begin{array}{c}\text { Metal ion*/ } \\
\text { Concentration }\end{array}$ & Accumulation \& Toxicity & Reference \\
\hline \multirow[t]{5}{*}{1} & \multirow[t]{5}{*}{$\begin{array}{l}\text { Sunflower } \\
\text { (Helianthus } \\
\text { annuus L.) }\end{array}$} & $\begin{array}{l}\text { Experimental } \\
\text { Water }\end{array}$ & $\begin{array}{l}\mathrm{Cu}^{2+} 0.64,6.36, \\
63.55 \text { (mg/L) }\end{array}$ & $\begin{array}{l}\text { accumulation is mainly in roots with } \\
\text { increase in root length, } 25 \text { times } \\
\text { accumulation in roots at } 10^{-3} \text { as } \\
\text { compared to control, high level } \\
\text { inhibits shoot growth } \\
\text { No Cu toxicity, potential ability to } \\
\text { accumulate Cu }\end{array}$ & Lin et al., 2003 \\
\hline & & $\begin{array}{l}\text { Experimental } \\
\text { Water }\end{array}$ & $\begin{array}{l}\mathrm{Ni} \\
0, \quad 10, \quad 20,30, \\
40(\mathbf{m g} / \mathbf{L})\end{array}$ & $\begin{array}{l}\text { Phytotoxic effect at all level of } \mathrm{Ni} \text {. At } \\
\text { high level reduction in root and shoot } \\
\text { biomass } \\
\text { Ni stress causes decrease in macro and } \\
\text { micro nutrients in leaves and achenes } \\
\text { e.g. Ca, Mn, Fe, N, K, Zn and Cu }\end{array}$ & Ahmad et al., 2011 \\
\hline & & Tannery Sludge & $\mathrm{Cr}, \mathrm{Fe}, \mathrm{Zn}, \mathrm{Mn}$ & $\begin{array}{l}\text { Increasing ratio of tannery sludge } \\
\text { amendments caused a progressive } \\
\text { increase in the accumulation of metals } \\
\text { maximum in roots > shoots > leaves } \\
\text { and least in seeds } \\
\text { Metal accumulation of the order Fe }> \\
\mathrm{Cr}>\mathrm{Mn}>\mathrm{Zn}\end{array}$ & $\begin{array}{l}\text { Singh et al., 2004, } \\
\text { Andaleeb et al., } \\
2008\end{array}$ \\
\hline & & - & $\mathrm{Pb}, \mathrm{U}, \mathrm{Pu}$ & Effective in removing & $\begin{array}{l}\text { Kumar et al., 1995, } \\
\text { Glass, 1998, Lee et } \\
\text { al., } 2002\end{array}$ \\
\hline & & $\begin{array}{l}\text { Soil } \\
\text { contaminated } \\
\text { amendment } \\
\text { using AM } \\
\text { fungus }\end{array}$ & $\mathrm{Cr}$ & $\begin{array}{l}\text { AM enhances } \mathrm{Cr} \text { uptake and plant } \\
\text { tolerance on growth. Cr accumulation } \\
\text { was greatest in roots intermediate in } \\
\text { shoots and leaves and lowest in } \\
\text { flowers }\end{array}$ & $\begin{array}{l}\text { Davies, Jr. et al., } \\
2001\end{array}$ \\
\hline
\end{tabular}




\begin{tabular}{|c|c|c|c|c|c|}
\hline & & $\begin{array}{l}\text { Metal } \\
\text { Contaminated } \\
\text { Soil }\end{array}$ & Cd and Zn & $\begin{array}{l}\text { An increased antioxidant level } \\
\text { corresponded to a high Cd and Zn } \\
\text { accumulation in young and adult } \\
\text { sunflowers } \\
\text { Antioxidant enzymes in seedlings and } \\
\text { adult sunflower mutants with } \\
\text { improved metal removal traits on a } \\
\text { metal-contaminated soil }\end{array}$ & $\begin{array}{l}\text { Nehnevajova et al, } \\
2012\end{array}$ \\
\hline \multirow[t]{5}{*}{2} & \multirow[t]{5}{*}{$\begin{array}{l}\text { Mustard } \\
\text { (Brassica } \\
\text { juncea) }\end{array}$} & $\begin{array}{l}\text { Soil } \\
\text { contaminated } \\
\text { and amendment } \\
\text { using EDTA }\end{array}$ & $\mathrm{Zn}, \mathrm{Pb}$ and $\mathrm{Cd}$ & $\begin{array}{l}\mathrm{Pb} \text { in roots increase and concentration } \\
\text { small amount transported to } \\
\text { hypocotyls and shoot. At high Conc. } \\
\text { root growth decreases }\end{array}$ & Wu et al., 2004 \\
\hline & & $\begin{array}{l}\text { Hydroponically } \\
\text { in experimental } \\
\text { water }\end{array}$ & $\begin{array}{l}\mathrm{Pb}^{2+} \\
\text { 2.07, 20.72, } \\
207.2(\mathrm{mg} / \mathrm{L})\end{array}$ & $\begin{array}{l}\text { Inhibits growth of roots, hypocotyls } \\
\text { and shoot at } 10^{-3} \mathrm{M} \text {. At lower } \\
\text { concentration accumulates primarily in } \\
\text { roots }\end{array}$ & Liu et al. 2000 \\
\hline & & $\begin{array}{l}\text { Metal } \\
\text { contaminated } \\
\text { soil, } \\
\text { amendment } \\
\text { using NTA and } \\
\text { Citric acid for } \\
\text { metal solubility }\end{array}$ & $\begin{array}{l}\mathrm{Cd}, \mathrm{Cr}, \mathrm{Cu}, \mathrm{Pb} \\
\text { and } \mathrm{Zn}\end{array}$ & $\begin{array}{l}\text { Desorption of metals from the soil } \\
\text { increased with chelate conc., NTA } \\
\text { being more effective than citric acid. } \\
\text { NTA treatment increased shoot metal } \\
\text { conc.by a factor 2-3. Cr detected in the } \\
\text { above ground tissues after NTA } \\
\text { amendment. }\end{array}$ & $\begin{array}{l}\text { Quartacci et al., } \\
2006\end{array}$ \\
\hline & & $\begin{array}{l}\text { Mixed } \\
\text { distillery and } \\
\text { tannery } \\
\text { effluents }\end{array}$ & $\begin{array}{l}\mathrm{Cu}, \mathrm{Cd}, \mathrm{Cr}, \mathrm{Zn} \text {, } \\
\mathrm{Fe}, \mathrm{Ni}, \mathrm{Mn} \text {, and } \\
\mathrm{Pb}\end{array}$ & $\begin{array}{l}\mathrm{Fe}>\mathrm{Mn} \text { and } \mathrm{Zn} \text { in root }>\text { shoot }> \\
\text { leaves }>\text { seeds }\end{array}$ & Chandra et al, 2009 \\
\hline & & $\begin{array}{l}\text { Soil } \\
\text { contaminated } \\
\text { with heavy } \\
\text { metal and } \\
\text { amendment } \\
\text { using growth }\end{array}$ & $\mathrm{Cr}^{6+}$ & $\begin{array}{l}\text { Accumulation of chromium in root } \\
\text { and shoot system }\end{array}$ & $\begin{array}{l}\text { Rajkumar et al., } \\
2006\end{array}$ \\
\hline
\end{tabular}




\begin{tabular}{|c|c|c|c|c|c|}
\hline & & $\begin{array}{l}\text { promoting } \\
\text { bacteria } \\
\text { (PGPB) }\end{array}$ & & & \\
\hline \multirow[t]{2}{*}{3} & \multirow[t]{2}{*}{$\begin{array}{l}\text { Sesame } \\
\text { (Sesamum } \\
\text { indicum (L.) }\end{array}$} & tannery sludge & $\begin{array}{l}\text { K, Na, Fe, Zn, } \\
\mathrm{Cr}, \mathrm{Mn}, \mathrm{Cu}, \mathrm{Pb} \text {, } \\
\mathrm{Ni} \text { and } \mathrm{Cd}\end{array}$ & $\begin{array}{l}\text { Accumulation in the order } \mathrm{K}>\mathrm{Na}> \\
\mathrm{Fe}>\mathrm{Zn}>\mathrm{Cr}>\mathrm{Mn}>\mathrm{Cu}>\mathrm{Pb}>\mathrm{Ni}> \\
\mathrm{Cd} \text { and its translocation was found less } \\
\text { in upper part }\end{array}$ & $\begin{array}{l}\text { Gupta and Sinha, } \\
2006\end{array}$ \\
\hline & & $\begin{array}{l}\text { organic waste } \\
\text { compost }\end{array}$ & $\begin{array}{l}\mathrm{Fe}, \mathrm{Mn}, \mathrm{Zn}, \\
\mathrm{Cu}, \mathrm{Co}, \mathrm{Ni}, \mathrm{Cd}, \\
\mathrm{Pb}\end{array}$ & $\begin{array}{l}\text { Maximum level of tested metals in } \\
\text { seeds did not exceed pytotoxicity level }\end{array}$ & $\begin{array}{l}\text { Abdel-Sabour and } \\
\text { El-Seoud, } 1996\end{array}$ \\
\hline \multirow[t]{2}{*}{4} & \multirow{2}{*}{$\begin{array}{l}\text { Castor } \\
\text { (Ricinus } \\
\text { communis } \\
\text { L.) }\end{array}$} & $\begin{array}{l}\text { Experimental } \\
\text { Soil }\end{array}$ & $\begin{array}{l}\text { Cd } \\
50,100,200 \\
\mu g / g\end{array}$ & $\begin{array}{l}\text { Castor, Hemp, Flax and Peanut more } \\
\text { tolerant to Cd toxicity than Rapeseed, } \\
\text { Sunflower, Soybean and Safflower }\end{array}$ & Shi and Cai (2009) \\
\hline & & $\begin{array}{l}\text { Soil } \\
\text { contaminated } \\
\text { with lubricating } \\
\text { oil (SLO) }\end{array}$ & $\begin{array}{l}\text { Mn, Ni, V and } \\
\mathrm{Pb}\end{array}$ & $\begin{array}{l}\mathrm{Mn}, \mathrm{Ni} \text {, and } \mathrm{Pb} \text { mostly accumulated in } \\
\text { leaves while } \mathrm{V} \text { was highest in roots }\end{array}$ & $\begin{array}{l}\text { (Vwioko et. al, } \\
\text { 2006) }\end{array}$ \\
\hline \multirow[t]{2}{*}{5} & \multirow[t]{2}{*}{$\begin{array}{l}\text { Rapeseed } \\
\text { (Brassica } \\
\text { napus) }\end{array}$} & $\begin{array}{l}\text { Plants grown } \\
\text { hydroponically }\end{array}$ & $\begin{array}{l}\text { Zn } \\
4.58,9.15, \\
\text { 18.31, 36.62, } \\
66.69(\mathrm{mg} / \mathrm{L})\end{array}$ & $\begin{array}{l}\text { Zn necessary element for plants, } \\
\text { excess Zn can be detrimental. }\end{array}$ & Wang et. al, 2009 \\
\hline & & $\begin{array}{l}\text { Plants watered } \\
\text { by } \mathrm{ZnSO}_{4} 2000 \\
\mu \mathrm{M} \text { or } \mathrm{CdCl}_{2} \\
250 \mu \mathrm{M}\end{array}$ & $\begin{array}{l}\mathrm{ZnSO}_{4} \text { and } \\
\mathrm{CdCl}_{2}\end{array}$ & $\begin{array}{l}\text { Cultiver (Jumbo and Drakkar) } \\
\text { resistant to Zn and Cd stress, were } \\
\text { more efficient in phyto extraction and } \\
\text { showed increased Zn and Cd } \\
\text { accumulation in all parts of the plants }\end{array}$ & Ghnaya et. al, 2009 \\
\hline
\end{tabular}

* For the ionic state refer to original papers 